\title{
Biological Attributes of Rice Sheath Mite, Steneotarsonemus spinki Smiley on Alternate Hosts of Rice
}

\author{
S.D. Chaudhari ${ }^{1 *}$ and P.D. Ghoghari ${ }^{2}$ \\ ${ }^{1}$ Depepartment of Entomology, N. M. College of Agriculture, NAU, Navsari, Gujarat, India \\ ${ }^{2}$ Main Rice Research Centre, N.A.U., Navsari, Gujarat, India \\ *Corresponding author
}

\section{A B S T R A C T}

\begin{tabular}{|l|}
\hline Ke y w or d s \\
Steneotarsonemus \\
spinki, Echinochloa \\
colonum, Cyperus \\
rotundus, \\
Morphometrics, Life \\
cycle
\end{tabular}

The biology and morphometrics of Steneotarsonemus spinki Smiley on alternate hosts of rice: Jungle rice (Echinochloa colonum L.) and Nut grass (Cyperus rotundus L.) were studied in laboratory conditions. The average incubation period of $S$. spinki was $2.75 \pm$ 0.679 days and $2.4 \pm 0.476$ days on $E$. colonum and $C$. rotundus, respectively. The total larval period of $S$. spinki was $2.5 \pm 0.513$ and $3.45 \pm 0.626$ days on E. colonum and $C$. rotundus. The quiescent period was $0.591 \pm 0.202$ day and $0.688 \pm 0.372$ day on $E$. colonum and $C$. rotundus, respectively. The male and female longevity of $S$. spinki was $3.15 \pm 1.203$ days and $4.05 \pm 0.643$ days on E. colonum, whereas it was $2.8 \pm 0.715$ days and $3.7 \pm 0.888$ days on $C$. rotundus. The pre-oviposition period was 1 to 2.5 days on $E$. colonum and $C$. rotundus. The oviposition periods of $S$. spinki varied from 0.5 to 2.5 days and 1 to 2 days on E. colonum and C. rotundus, respectively. The post oviposition period of $S$. spinki was 1 to 2 on E. colonum and C. rotundus. Total life cycle of $S$. spinki male occupied $8.70 \pm 1.316$ days and $8.95 \pm 1.342$ days in case of $E$. colonum and $C$. rotundus. Female required $9.60 \pm 1.486$ days and $9.85 \pm 1.313$ days on E. colonum and $C$. rotundus, respectively.

\section{Introduction}

Asia is considered to be "rice bowl" of world, where more than 90 per cent of world's rice is produced and consumed. It is one of the oldest and second most intensively grown cereal crops of the world next to wheat and rank third in grain production. The area covered under rice in the world is 161.16 million hectares with an average production of 478.69 million metric tonnes. India is an important centre of rice cultivation. India has the largest area of 44.11 million hectares with an annual production and productivity were 105.48 million metric tonnes and $2391 \mathrm{~kg} / \mathrm{ha}$, respectively (Anonymous, 2014-15). Gujarat is an important rice growing state of the India which occupies an area of 0.786 million hectares producing 1.830 million tonnes with an average productivity of $2329 \mathrm{~kg} / \mathrm{ha}$ (Anonymous, 2014-15).

Among the pests, sheath mites (Steneotarsonemus spinki Smiley) which belong to family Tarsonemidae infests flag leaf sheath of rice causing brown 
discoloration. Infestation of this mite on panicle causes chaffy grains and also discoloration of filled or ill-filled grains (Srinivasa et al., 2004). Feeding of these mites on reproductive parts of flowers results in grain sterility (Rao et al., 2000). There were many alternate hosts on which $S$. spinki continue their development and growth that affect the rice crop later. Rao and Prakash (2002) reported a weed, Schoenoplectus articulatus (Cyperaceae) as an alternate host of $S$. spinki during the field surveys at CRRI, Cuttack, and Orissa. Khimji (2005) observed that $S$. spinki survived on two graminaceous weed plants viz., Cyprus difformis and Cynodon dactylon and on post-harvest remain of rice crops during off season and served as source of infestation for next kharif season. Srinivasa and Prabhakara (2007) reported that eggs and active stages of $S$. spinki were noticed on leaves of other graminaceous weeds Cyanodon dactylon and Echinochloa sp. and collected the sample from the vicinity of the rice fields in Karnataka. Chandrasena et al., (2016) in Sri Lanka, observed that Sacciolepis interrupta act as an alternate host of the S. spinki, while Echinochloa crus-galli and Leptochloa chinensis play minor role. Recently, in India this mite was observed to cause significant reduction in yield of rice crop in Gujarat and West Bengal (Anonymous, 2007-09). Incidence of S. spinki was noticed first time in 1993 from paddy field in south Gujarat (Rai et al., 1998). The occurrence of rice sheath mite has increase in south Gujarat since few years and has become major problem in rice cultivation as it reduce quality and quantity of rice production. So that the study of sheath mite behavior present investigation was carried out during kharif 2016.

\section{Materials and Methods}

The study on biology of Steneotarsonemus spinki was carried out in the laboratory,
Department of Entomology, N. M. College of Agriculture, Navsari Agricultural University, Navsari at $31.1 \pm 0.9{ }^{\circ} \mathrm{C}$ and $28.9 \pm 0.6{ }^{\circ} \mathrm{C}$ average of maximum and minimum laboratory temperature with $54.8 \pm 15.18$ per cent and $69.3 \pm 11.4$ per cent mean of morning and evening relative humidity, respectively.

\section{Maintenance of sheath mite culture}

Stock culture of rice sheath mite, S. spinki Smiley was maintained both on rice leaf sheath and rice grown in pots. Initially severely infested leaves with rice sheath mite, $S$. spinki Smiley collected from rice field of Main Rice Research Centre, N.A.U., Navsari and surrounding fields were stapled on potted rice plants for mass multiplication of sheath mites during kharif 2016.

\section{Alternate hosts}

Rice sheath mite, $S$. spinki which infest first on rice crop. Some weeds of graminae family are the alternate hosts of rice sheath mite. Hence, graminaceous weeds in the fields as well as surrounding area were observed and bring the infected weeds to the laboratory for study the biology of $S$. spinki on it, according to methodology mention for the rice.

\section{Method of observation}

A stereo binocular microscope was used for critical observations on behavior, colour, morphology and other attributes of the mite in different stages. Laboratory temperature (minimum and maximum) and relative humidity (morning and evening) were recorded daily by using dry and wet bulb thermometer during the period of study. A stereo trinocular microscope olympus-SZ (16) fitted with Brand Catcam-130 camera having software power Scopephoto was used for measuring the size of various stages of rice sheath mite. 
Before using the leaf for different experiments, the healthy green leaves selected from potted plants were thoroughly washed with tap water, dried it and examined under stereo binocular microscope to remove or kill any insect or mite stages found on them. Ten gravid females obtained from mass culture were released on a transversely cut leaf sheath pieces over moist cotton swab kept in petri dish by a fine camel hair brush employing a stereo binocular microscope in the morning hours. On next day, the leaves were carefully observed for eggs. Then the females were transferred to another set for egg laying with the help of fine camel hair brush under stereo binocular microscope. The eggs so obtained were used for details biological study of rice sheath mite. The cotton swabs were kept saturated with water from time to time. So that the leaves may remain in fresh condition for longer time. The old leaves were replaced periodically with new fresh leaves so as to ensure their good quality. Newly emerged larvae was transferred and released individually on fresh leaf sheaths.

When matured larvae entered into quiescent stage, it was then transferred to new leaf sheath and kept under careful observations even at two hours interval for recording the length of its short period. On adult formation some specimens were observed critically both under stereo-binocular microscope and slide microscope for detailed morphological features. Other live specimens separated as male and females, paired and released individually in pair on different leaves and observed again twice a day for starting of egg laying and pre oviposition period was noted. The gravid female carefully picked up with fine camel hair brush and released on fresh leaf at 24 hours interval to record daily egg laying and fecundity of female. The post oviposition period was also recorded. The longevity of male and female were recorded separately by rearing individuals in each category. Total life cycle from egg to adult and sex ratio was recorded in laboratory conditions.

\section{Results and Discussion}

The study on biology of Rice sheath mite, Steneotarsonemus spinki was carried out in the laboratory during kharif 2016. Looking to the infestation of $S$. spinki on rice crop and its associated weeds, we have taken two weeds. They were Jungle rice (Echinochloa colonum L.) and Nut grass (Cyperus rotundus L.) as alternate host for studying the biology.

Eggs were laid by adult female in intracellular space of leaf and on the leaf in laboratory condition. The eggs laid either singly or in masses in small clusters and each cluster consist of 2 to 5 eggs. The eggs were slightly sticked with the inner surface of leaf sheaths. Eggs were cloudy, creamy white, yellowish white and elongated. As time progressed, it turned more whitish. Eggs of $S$. spinki measured 0.12 to $0.14 \mathrm{~mm}$ in length and 0.132 $\pm 0.006 \mathrm{~mm}$ in width and $0.137 \pm 0.007 \mathrm{~mm}$ in length and $0.075 \pm 0.007 \mathrm{~mm}$ in width on $E$. Colonum and $C$. rotundus, respectively (Table 2 ). The average incubation period of $S$. spinki was $2.75 \pm 0.679$ days and $2.4 \pm 0.476$ days on E. colonum and $C$. rotundus, respectively. Total hatching percentage of $S$. spinki was recorded 71.05 per cent and 67.71 per cent on E. colonum and C. rotundus, respectively (Table 1).

The newly hatched larvae of rice sheath mite, $S$. spinki were opaque and white in colour. Male larvae of $S$. spinki measured $0.147 \pm$ $0.009 \mathrm{~mm}$ in length and $0.08 \pm 0.008 \mathrm{~mm}$ in width. Female larvae measured $0.175 \pm 0.016$ $\mathrm{mm}$ in length and $0.074 \pm 0.005 \mathrm{~mm}$ in width on E. colonum. Whereas on $C$. rotundus, length of male larvae measured $0.145 \pm 0.011$ $\mathrm{mm}$ and width measured with an average of $0.081 \pm 0.007 \mathrm{~mm}$. 
Table.1 Total life cycle of rice sheath mite, S. spinki on alternate hosts of rice

\begin{tabular}{|c|c|c|c|c|c|c|c|}
\hline \multirow{3}{*}{$\begin{array}{l}\text { Sr. } \\
\text { No. }\end{array}$} & \multirow{3}{*}{$\begin{array}{c}\text { Developmental } \\
\text { stages of } S \text {. spinki }\end{array}$} & \multicolumn{6}{|c|}{ Duration in days } \\
\hline & & \multicolumn{3}{|c|}{ E. colonum } & \multicolumn{3}{|c|}{ C. rotundus } \\
\hline & & Min. & Max. & Av. \pm S. D. & Min. & Max. & Av. \pm S. D. \\
\hline 1 & Incubation period & 1.5 & 3.5 & $2.75 \pm 0.679$ & 1.5 & 3.0 & $2.40 \pm 0.476$ \\
\hline 2 & Larval period & 1.5 & 3.0 & $2.50 \pm 0.513$ & 2.5 & 4.5 & $3.45 \pm 0.626$ \\
\hline 3 & Quiescent period & 0.5 & 1.0 & $0.591 \pm 0.202$ & 0.5 & 1.5 & $0.688 \pm 0.372$ \\
\hline \multirow[t]{3}{*}{4} & \multicolumn{7}{|l|}{ Adult } \\
\hline & Male & 1.0 & 5.0 & $3.15 \pm 1.203$ & 1.5 & 4.0 & $2.8 \pm 0.715$ \\
\hline & Female & 3.0 & 5.0 & $4.05 \pm 0.643$ & 2.0 & 5.0 & $3.7 \pm 0.888$ \\
\hline \multirow[t]{3}{*}{5} & \multicolumn{7}{|l|}{ Total life cycle } \\
\hline & Male & 7.0 & 11 & $8.70 \pm 1.316$ & 7.0 & 11.5 & $8.95 \pm 1.342$ \\
\hline & Female & 7.5 & 12.5 & $9.60 \pm 1.486$ & 8.0 & 12 & $9.85 \pm 1.313$ \\
\hline 6 & Pre-oviposition period & 1.0 & 2.5 & $1.55 \pm 0.369$ & 1.0 & 2.5 & $1.6 \pm 0.459$ \\
\hline 7 & Oviposition period & 0.5 & 2.5 & $1.6 \pm 0.516$ & 1.0 & 2.0 & $1.5 \pm 0.408$ \\
\hline 8 & Post-oviposition period & 1.0 & 2.0 & $1.45 \pm 0.369$ & 1.0 & 2.0 & $1.55 \pm 0.369$ \\
\hline 9 & Fecundity & 10 & 22 & $15.2 \pm 3.736$ & 05 & 20 & $12.7 \pm 5.250$ \\
\hline 10 & Sex ratio & - & - & $1: 1.45$ & - & - & $1: 1.38$ \\
\hline 11 & Hatching percentage $(\%)$ & 44.45 & 100 & 71.05 & 40 & 83.34 & 67.71 \\
\hline
\end{tabular}

Table.2 Morphometrics of rice sheath mite, S. spinki on alternate hosts of rice

\begin{tabular}{|l|c|c|c|c|}
\multicolumn{1}{c}{$\begin{array}{c}\text { Stages } \\
\text { of S. spinki }\end{array}$} & \multicolumn{2}{c|}{ E. colonum } & \multicolumn{2}{c|}{ C. rotundus } \\
\cline { 2 - 5 } & Length (mm) & Width (mm) & Length (mm) & Width (mm) \\
\cline { 2 - 5 } & Av. \pm S. D. & Av. \pm S. D. & Av. \pm S. D. & Av. \pm S. D. \\
\hline Eggs & $0.132 \pm 0.006$ & $0.069 \pm 0.006$ & $0.137 \pm 0.007$ & $0.075 \pm 0.007$ \\
\hline Immature: & & & & \\
\hline Male & $0.147 \pm 0.009$ & $0.08 \pm 0.008$ & $0.145 \pm 0.011$ & $0.081 \pm 0.007$ \\
\hline Female & $0.175 \pm 0.016$ & $0.074 \pm 0.005$ & $0.158 \pm 0.015$ & $0.072 \pm 0.004$ \\
\hline Quiescent & $0.22 \pm 0.025$ & $0.076 \pm 0.008$ & $0.22 \pm 0.31$ & $0.076 \pm 0.008$ \\
\hline Adult: & & & & \\
\hline Male & $0.076 \pm 0.008$ & $0.202 \pm 0.02$ & $0.197 \pm 0.022$ & $0.098 \pm 0.004$ \\
\hline Female & $0.232 \pm 0.02$ & $0.071 \pm 0.009$ & $0.235 \pm 0.016$ & $0.075 \pm 0.01$ \\
\hline
\end{tabular}


Female larvae measuring $0.158 \pm 0.015 \mathrm{~mm}$ in length and $0.072 \pm 0.004 \mathrm{~mm}$ in width (Table 2). The total larval period of $S$. spinki was $2.5 \pm 0.513$ and $3.45 \pm 0.626$ days on $E$. colonum and $C$. rotundus, respectively which was quite similar to each other (Table 1).

The mature larvae entered into a quiescent stage and feeding of the larvae was restricted. Quiescent stage of $S$. spinki measured $0.22 \pm$ $0.025 \mathrm{~mm}$ length and $0.076 \pm 0.008 \mathrm{~mm}$ width and $0.22 \pm 0.31 \mathrm{~mm}$ in length and 0.076 $\pm 0.008 \mathrm{~mm}$ in width on $E$. Colonum and $C$. rotundus, respectively. During this period, the mite suspended all its activity of feeding. The quiescent period of $S$. spinki observed rarely and it was almost equal on E. colonum and $C$. rotundus. The quiescent period was $0.591 \pm$ 0.202 day and $0.688 \pm 0.372$ day on $E$. colonum and C. rotundus (Table 1 ).

Male and female of $S$. spinki were transparent white in colour. Male was shorter in length and broader in width as compare to female. Male of $S$. spinki measured $0.076 \pm 0.008 \mathrm{~mm}$ in length and $0.202 \pm 0.02 \mathrm{~mm}$ in width and $0.197 \pm 0.022 \mathrm{~mm}$ in length and $0.098 \pm$ $0.004 \mathrm{~mm}$ in width on E. Colonum and $C$. rotundus, respectively. Female of $S$. spinki measured $0.232 \pm 0.02 \mathrm{~mm}$ in length and $0.071 \pm 0.009 \mathrm{~mm}$ in width and $0.235 \pm 0.016$ $\mathrm{mm}$ in length and $0.075 \pm 0.01 \mathrm{~mm}$ in width on E. Colonum and C. rotundus, respectively (Table 2). The male and female longevity of S. spinki was $3.15 \pm 1.203$ days and $4.05 \pm$ 0.643 days on E. colonum. The male and female longevity of $S$. spinki was $2.8 \pm 0.715$ days and $3.7 \pm 0.888$ days on $C$. rotundus (Table 1).

The pre-oviposition period was 1 to 2.5 days on E. colonum and $C$. rotundus. The oviposition periods of $S$. spinki varied from 0.5 to 2.5 days and 1 to 2 days on E. colonum and $C$. rotundus, respectively. The post oviposition period of $S$. spinki varied from 1 to 2 on E. colonum and C. rotundus. Total fecundity of $S$. spinki was found to be $15.2 \pm$ 3.736 eggs/female and $12.7 \pm 5.25$ eggs/female on E. colonum and C. rotundus, respectively. When rice sheath mites, $S$. spinki reared on $E$. colonum and $C$. rotundus sex ratio of male to female were $1: 1.45$ and $1: 1.38$ (Table 1).

In case of $E$. colonum, total life cycle for $S$. spinki male was $8.70 \pm 1.316$ days and $9.60 \pm$ 1.486 days for female. $S$. spinki male completed its life cycle in $8.95 \pm 1.342$ days and female required $9.85 \pm 1.313$ days on $C$. rotundus (Table 1 ).

\section{References}

Anonymous, (2007-09). Project report, All India Network Project on Agricultural Acarology, 40-41.

Anonymous, (2014-15). Data of rice area, production and productivity of 2014-15. Ministry of Agriculture and Farmers Welfare, Govt. of India. (http://www.indiastat.com/table/agricult ure/2/rice/17194/36196/data.aspx)

Chandrasena, G. D. S. N., Jayawardane, J. D. K. M., Umange, S. D., Gunawardana, A. D. B. U. (2016). Host Range of Panicle Rice Mite Steneotarsonemus spinki Smiley (Acari: Tarsonemidae) in Sri Lanka. Universal Journal of Agricultural Research, 4(1): 21-24.

Khimji, A. B. (2005). Bioecology and management of rice sheath mite, Steneotarsonemus spinki Smiley (Acari: Tarsonemidae). Ph.D. (Agri.) Thesis submitted to NAU, Navsari.

Rai, A. B., Patel, J. R., Desai, H. R. and Patel, A. J. (1998). Plant mites of agricultural importance in Gujarat. In: National Seminar on Entomology in $21^{\text {st }}$ Century organized by Entomological Society of India at Rajasthan College of 
Agriculture, Udaipur (Rajasthan) from April 30 to May 2, 1998.

Rao, J. and Prakash, A., (2002). Paddy field weed, Schoenoplectus articulatus (Linn.) Palla (Cyperaceae): a new host of tarsonemid mite, Steneotarsonemus spinki Smiley and panicle thrips, Haplothrips ganglbaureri Schmutz, J. Appl. Zool. Res., 13(2/3): 174-175.

Rao, P. R. M., Bhavani, B., Rao, T. R. M. and Reddy, P. R. (2000). Spikelet sterility/grain discolouration in rice in
Andhra Pradesh, India. Int. Rice Res. Notes, 25(3): 40.

Srinivasa, N. and Prabhakara, H., (2007). Survival of sheath mite Steneotarsonemus spinki in the rice ecosystem. J. Acarol., 16(1 and 2): 6264.

Srinivasa, N., Prabhakara, H. and Mallik, B. (2004), Rice sheath mite Steneotarsonemus spinki Smiley (Acari: Tarsonemidae) A status paper, AINP Agril. Acarology, Bangalore, 24p.

\section{How to cite this article:}

Chaudhari, S.D. and Ghoghari, P.D. 2018. Biological Attributes of Rice Sheath Mite, Steneotarsonemus spinki Smiley on Alternate Hosts of Rice. Int.J.Curr.Microbiol.App.Sci. 7(02): 1596-1601. doi: https://doi.org/10.20546/ijcmas.2018.702.192 